\title{
Comparative Study of Dye Decolorization using free and Alginate Gel Entrapped Laccase from Cercospora sp. SPF-6
}

\author{
Vikram Thakur*, Pradeep Kumar, Anita Verma, Jeevan Lata and Duni Chand* \\ Department of Biotechnology, Himachal Pradesh University, India
}

Submission: June 24,2018; Published: September 21, 2018

*Corresponding author: Duni Chand, Department of Biotechnology, Multy Faculty Building (Phase-1), Gyan Path, Himachal Pradesh University Campus, Summer Hill, Shimla-171005 (H.P), India, Tel: +09418276448; Fax +91-177-2832154; Email: dunichand_2000@yahoo.com

*Vikram Thakur: Department of Virology, Postgraduate Institute of Medical Education and Research, PGIMER, Sec-12, Chandigarh, India, Tel: +91 8054972711; Email: vik5atif@gmail.com

\begin{abstract}
Laccase have a promising potential to be used as a bio-remediating agent that can be used to solve various environmental issues. In this study, extracellular laccase enzyme was produced from Cercospora sp SPF-6 isolated from the soils of Himachal Pradesh and was immobilized by entrapment in calcium alginate beads with immobilization efficiency of $72.42 \%$ and enzyme activity of $0.617 \mathrm{U} /$ gel was assessed for its dye decolorization potential. Free laccase showed maximum decolorization of methyl orange dye at $35{ }^{\circ} \mathrm{C}$ in 90 min with citrate phosphate buffer $(0.1$ $\mathrm{M}, \mathrm{pH}$ 3.0) as compared to immobilized enzyme at $25^{\circ} \mathrm{C}$ with the same buffer $(0.025 \mathrm{M}, \mathrm{pH} 2.5)$ in $30 \mathrm{~min}$. At $50 \mathrm{ml}$ flask scale with same optimized conditions, the free enzyme in fed batch showed $99.4 \%$ decolorization compared to batch and with immobilized enzyme both batch and fed batch showed approximately $77 \%$ dye decolorization. In the BRUNSWICK fermenter $(500 \mathrm{ml})$, with immobilized enzyme, batch and fed batch showed $68 \%$ and $72 \%$ decolorization respectively (1.36IU x 6,000 beads). Immobilized enzyme showed reusability upto 7 th reaction cycle with $50 \%$ decolorization efficiency. These preliminary results suggested that immobilized laccase in alginate beads can be potentially developed for large scale bioremediation of other toxic dyes with bioreactors.
\end{abstract}

Keywords: Cercospora sp. SPF-6; Brunswick fermenter; Immobilization; Laccase; Alginate

Abbreviations: ABTS: 2,2'-Azinobis,3-EthylBenzothiazoline-6-Sulphonic Acid; BSA: Bovine serum lbumin; HOBt: Hydroxybenzotriazole; IU: International Unit; PABA: 4-Aminobenzoic Acid; PDA: Potato Dextrose Agar; p-HBA: p-hydroxy benzoic acid; $\mu$ g: Microgram

\section{Introduction}

Rapid development of dye industry has accelerated the production and commercialization of dyes leading to serious environmental and health hazards. Waste water released by various synthetic dye industries can pollute and harm the aquatic environment [1,2]. Physical and electrochemical methods including coagulation, ion exchange, and oxidation for the removal of azo or recalcitrant dyes from the effluents become obsolete due to their technical and economical limitations [2] In the current decade biocatalysts being efficient have received great attention for synthetic dye decolorization and also generate no-toxic product [3].

Laccase being an oxido-reductase enzyme utilize oxygen (electron acceptor) to catalyze a variety of aromatic compounds and is far superior in degrading various recalcitrant pollutants [4]. Predominately distributed in plants, fungi and bacteria but the ability to transform hazardous chemicals using fungal laccase has aroused interest in using them in bioremediation.
So far, enzymatic treatment is considered an alternative method for making environment xenobiotic (toxic) free. Using molecular oxygen as oxidant and the fact that the water is only by-products are very attractive catalytic features, making laccase as an excellent Green Catalyst [5]. Immobilized enzyme preparations being reversible and more stable than free enzymes can be more effective and used repeatedly in bioreactor because they remain separated by different methods during the reaction [5]. Laccases from fungi offer several advantages of great interest to biotechnological applications.

Since laccase sex habit capability for degrading phenolic compounds, therefore it is important for bioremediation of industrial waste water. Recently, for the decolorization of wastewater the approach shifted towards enzyme based treatment. Munusi et al. [6] reported removal of naturally occurring and xenobiotic aromatic compounds using organic-gel immobilized laccase. Synthetic dyes such as Azure B, Brilliant Blue $\mathrm{R}$ and paper mill effluent were shown to decolorize 
using laccase from fungus Flavodon flavus. Since the recently existing wastewater (dye) treatment processes are ineffective and expensive, there is a need for the development of efficient enzyme based (laccase) processes.

Hence in this study, we described the immobilization of laccase by different methods such as entrapment and adsorption in alginate and silica and compared the efficiency for dye decolorization (methyl orange) with free and immobilized enzyme (laccase) using batch and fed-batch fermenter. To our knowledge, this is the first study using laccase from novel fungus Cercospora $s p$. and first ever comparative analysis of dye decolorization using both free and entrapped laccase.

\section{Materials and Methods}

\section{Chemicals and reagents}

High purity grade chemicals like veratryl alcohol, sodium azide, yeast extract, potato dextrose agar, soya meal, fructose, citric acid, agar and disodium hydrogen sulphate were obtained from Hi-Media Mumbai, INDIA. Methyl orange and 2,2'-azinobis,3-ethylbenzothiazoline-6-sulphonic acid (ABTS) were purchased from Sigma Aldrich (USA). Sodium alginate was obtained from Merck (Germany). BUCHI Switzerland B-390. Encapsulator, Bio Flo Neo Brunswick Scientific Co. Inc (U.S.A) fermenter and UV-VIS spectrophotometer were also used.

\section{Inoculum preparation and laccase production}

Laccase producing Cercospora sp. SPF- 6 was point inoculated from the master plate on potato dextrose agar (PDA) plates and was incubated at $30{ }^{\circ} \mathrm{C}$ for $96 \mathrm{hrs}$. These pre-cultures were used in production medium along with veratryl alcohol (5 drops, 1 $\mathrm{mM}$ ) for the production of extracellular laccase. Fungal culture discs (6 $\mathrm{mm}$ dia) were transferred in to an Erlenmeyer flask containing $100 \mathrm{ml}$ production medium (1.25\% soya meal, $1.8 \%$ fructose, $1 \%$ yeast extract, $3 \mu \mathrm{M} \mathrm{CuSO} 4.5 \mathrm{H} 2 \mathrm{O}, 10 \mu \mathrm{M} \mathrm{CaCl} 2.2 \mathrm{H} 2 \mathrm{O}$, $10 \mu \mathrm{M} \mathrm{MgCl} 2.2 \mathrm{H} 20$ at $\mathrm{pH} 6.0$ ) and was kept at $30^{\circ} \mathrm{C}$ at $150 \mathrm{rpm}$ for 108 hrs. After incubation, extracellular laccase was filtered with Whattman No. 1 filter paper (designated as free crude extract) and used for the enzyme assay.

\section{Assay condition and protein estimation}

Laccase activity was defined as the amount of enzyme catalyzing the oxidation of $1 \mu \mathrm{mol}$ of the substrate in one min under standard reaction condition and was determined by the modified method of Nagai et al. [7]. The assay included $100 \mu \mathrm{M}$ ABTS, $890 \mu$ l McIlvaine buffer ( $\mathrm{pH}$ 3.0) and $10 \mu$ l enzyme solution in $1 \mathrm{ml}$ reaction volume at $30{ }^{\circ} \mathrm{C}$ for $5 \mathrm{~min}$. By adding sodium azide ( $500 \mu \mathrm{l}, 3 \mathrm{mM})$, the reaction was stopped and activity was measured at $420 \mathrm{~nm}$.Protein estimation was done using the Bradford method and standard curve was prepared using 20$200 \mu \mathrm{g} / \mathrm{ml}$ of bovine serum albumin (BSA) [8].

\section{Immobilization of laccase in alginate and silica}

Laccase enzyme was immobilized by entrapment and adsorption on alginate and silica respectively. The optimized concentration of sodium alginate (2.5\%) with $\mathrm{CaCl} 2(0.2 \mathrm{M})$ and $\mathrm{Cu} 2 \mathrm{SO} 4(0.2 \mathrm{M})$ was prepared separately. Equal volumes of sodium alginate and crude enzyme was mixed and beads were prepared using BUCHI Switzerland B-390 Encapsulator at 30 ${ }^{\circ} \mathrm{C}$ into $0.2 \mathrm{M}$ ice cold solution of calcium chloride and copper sulphate, respectively. The beads were incubated overnight for curing in stirring condition and were washed with sterile distilled water before performing further experiment.

Laccase was adsorbed on silica (4g) with a minimum amount of sodium phosphate buffer $(0.1 \mathrm{M} ; \mathrm{pH})$. The mixture wasleft overnight for activation at room temperature and filtered with Whattman No.1 filter paper. $5 \mathrm{ml}$ of crude enzyme was added in $1 \mathrm{~g}$ of silica (pellets) and incubated for efficient binding in incubator shaker.

\section{Activity immobilization yield}

The active immobilization yield was calculated as described by Noeru \& Sawhney [9]:

$$
\gamma \frac{a c t}{I M E}=\frac{I M E}{S E i}
$$

Where, IME: Total activity yield of immobilized enzyme

SEi: Total activity of the free enzyme taken for immobilization.

Extent of decolorization was estimated with respect to decrease in optical density and calculated as percent decolorization as follow:

Where, $\left[\left(O D_{\text {Test }}-O D_{\text {Control }}\right) / O D_{\text {Test }}\right] \times 100$

OD Test represents optical density of the test

OD Control represents optical density of control

\section{Optimization of reaction parameters for dye decolorization using free and immobilized laccase}

Different reaction parameters like buffers, its morality, and wide $\mathrm{pH}$ range, incubation temperature and time, dye concentration and enzyme dose, different mediators and their concentrations.

\section{Effect of buffer, pH and molarity on dye decolorization}

To find out the best combination of buffer with $\mathrm{pH}$ and molarity for the maximum decolorization of methyl orange dye with both free and entrapped laccase, four buffer systems citrate phosphate $(\mathrm{pH} 2.5-4.5)$, sodium acetate ( $\mathrm{pH} 4.0-5.2)$, sodium ( $\mathrm{pH}$ 3.0-5.0) and sodium phosphate $(\mathrm{pH}$ 7.0-7.9) were prepared $(1 \mathrm{mM})$. The molarities of selected buffer was varied from 0.025 $\mathrm{M}$ to $0.1 \mathrm{M}$. The crude free enzyme and alginate entrapped laccase checked for the best buffer system.

\section{Optimization of reaction temperature and incubation time for dye decolorization}

Effect of temperature on the enzymatic decolorization was assessed by incubating the reaction mixture with free enzyme and as well as with immobilized enzyme at temperature ranging from $25{ }^{\circ} \mathrm{C}$ to $55^{\circ} \mathrm{C}$ with increment of $5{ }^{\circ} \mathrm{C}$. To determine the 
optimum reaction time for maximum dye decolorization incubation time ranging from 10 minutes to 360 minutes.

\section{Effect of enzyme dose and dye concentration}

To assess the effect of enzyme dose on decolorization, the reaction was started with different enzyme concentrations. Entrapped laccase in alginate with the activity of 3.09 IU to 18.09 IU $(20 \mu \mathrm{l}-200 \mu \mathrm{l})$ and in free form was incubated at an optimized temperature and time to check the decolorization potential using crude dye concentration varied from $20 \mathrm{mM}$ to $200 \mathrm{mM}$.

\section{Role of different mediators and their concentrations}

Laccase alone is not able to oxidize certain non-phenolic compounds, therefore highly active cation radicles production by oxidization of mediators using laccase is an effective way. Different mediators like 2,2'-azino-bis 3-ethylbenzothiazoline6-sulphonic Acid (ABTS), Hydroxybenzotriazole (HOBt), p-hydroxy benzoic acid (p-HBA), 4-Aminobenzoic Acid (PABA), Guaiacol, pyrogallol, hydroquinone, phylloquinone at the concentration of $1 \mathrm{mM}$ were used for their potential role to enhance the decolorization of dye.

\section{Reusability of immobilized enzyme in dye decolorization}

The Reusability of the laccase entrapped calcium alginate beads were investigated in selected buffer at optimized $\mathrm{pH}$ and temperature. Stability, efficiency (minimum cut off $50 \%$ decrease in dye decolorization) and reusability of the beads were checked by reusing the same beads at the end of each cycle to treat fresh methyl orange dye.

\section{Batch and fed batch decolorization of dye using Bio Flo Neo fermenter}

All optimized reaction parameters were used for pilot scale decolorization of dye $(500 \mathrm{ml})$ at both batch and fed batch mode using Brunswick fermenter. In batch mode, total dye at $1 \mathrm{mM}$ concentration was added at once and in fed batch equal feeding of dye was given to the reaction mixture at a defined interval of time to access efficient mode of decolorization.

\section{Results and Discussion}

\section{Laccase immobilization and matrices selection}

The amount of laccase (enzyme activity) retained by different matrices decides the binding efficiency and the application of that matrices. In the present study, laccase was immobilized broadly by two different methods i.e. entrapment in calcium and copper alginate and by adsorption on silica matrix. Spherical shaped alginate beads $(3.5 \mathrm{~mm})$ were obtained by encapsulator. However, the highest activity of immobilized enzyme was observed with calcium alginate (19.16 IU) followed by copper alginate beads (18.76IU) and silica matrix (12.09 IU) showed in Table 1. The observed variation in the immobilized laccase activity may be due to the concentration and pore size of matrix used. Researchers tried various matrices like oxirane acrylic beads, porosity glass, activated carbon and alumina to immobilize laccases of which calcium alginate is the most common due to simple gelation with $\mathrm{Ca} 2+[10,11]$. Maximum laccase binding efficiency $(72.42 \%)$ was observed with $2.5 \%$ calcium alginate at $0.2 \mathrm{M} \mathrm{CaCl} 2$ concentration as compared to silica (56.12\%). On decreasing the concentration of alginate below $2.5 \%$, resulted in enzyme leaching while increase in concentration beyond $2.5 \%$ failed to enhance the laccase binding efficiency. Calcium alginate beads exhibit higher binding efficiency and enzyme activity in comparison to other immobilised systems, hence proved to be the better support and was selected as best immobilization matrix for further studies.

Table 1: Selection of efficient matrices.

\begin{tabular}{|c|c|c|}
\hline Matrices & $\begin{array}{c}\text { Enzyme activity ( } \\
\text { IU) }\end{array}$ & $\begin{array}{c}\text { Immobilization } \\
\text { Efficiency (\%) }\end{array}$ \\
\hline Calcium alginate & 19.16 & 72.42 \\
\hline $\begin{array}{c}\text { Copper alginate } \\
\text { Silica } 60(0.060-0.2 \\
\text { mm) }\end{array}$ & 18.76 & 71.78 \\
\hline
\end{tabular}

\section{Suitable buffer system with optimized pH and molarity} for efficient dye decolorization

Crude enzyme showed maximum (72\%) dye decolorization with citrate phosphate buffer ( $\mathrm{pH} 3.0$ ) and immobilized enzyme displayed $83.02 \%$ decolorization at $\mathrm{pH} 2.5$ showed in Figure 1. Nyanhongo et al. [12] also showed the stability and activity of T. Modesta laccase at $\mathrm{pH} 4.0$ with decrease in half-life to $2 \mathrm{hr}$ at acidic $\mathrm{pH}$ 3.0. As $\mathrm{pH}$ altered, there was a decline in percent decolorization due to reduced affinity of active sites towards substrate at extreme pH. Our findings were in correlation with earlier reports from Palmieri et al. [13] for P. Ostreatus laccase, showing $\mathrm{pH}$ optima of 3.0-3.6 for substrate ABTS and suggested the transport of $\mathrm{H}+$ ion for mass transfer into the matrix. Citrate phosphate buffer with molarity $0.1 \mathrm{M}$ showed $63.25 \%$ dye decolorization with free enzyme and $72.33 \%$ with $0.025 \mathrm{M}$ for immobilized enzyme (Figure 2). The further increase or decrease in buffer molarity has adverse effect on the dye decolorization. Lu et al. [14] also reported phosphate citrate at a slightly higher concentration $(0.1 \mathrm{M})$ for alginate-chitosan immobilized laccase system. 


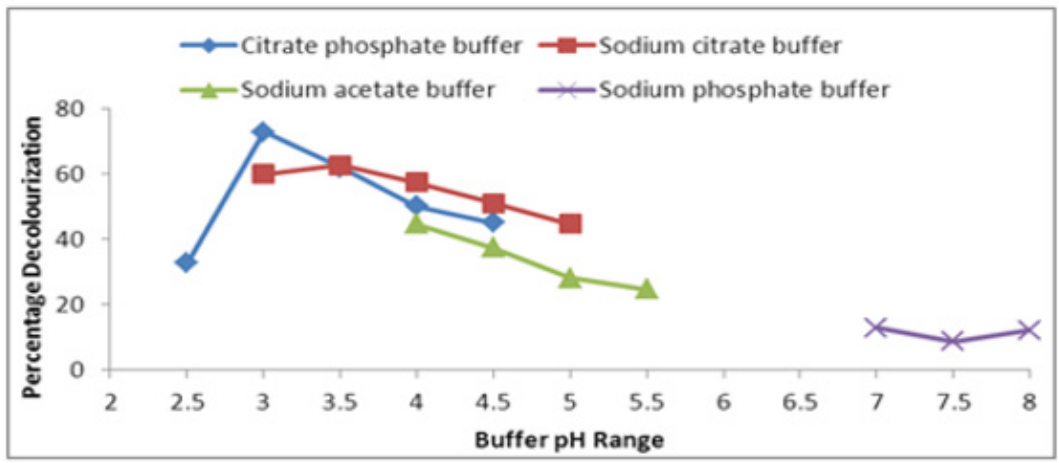

(a)

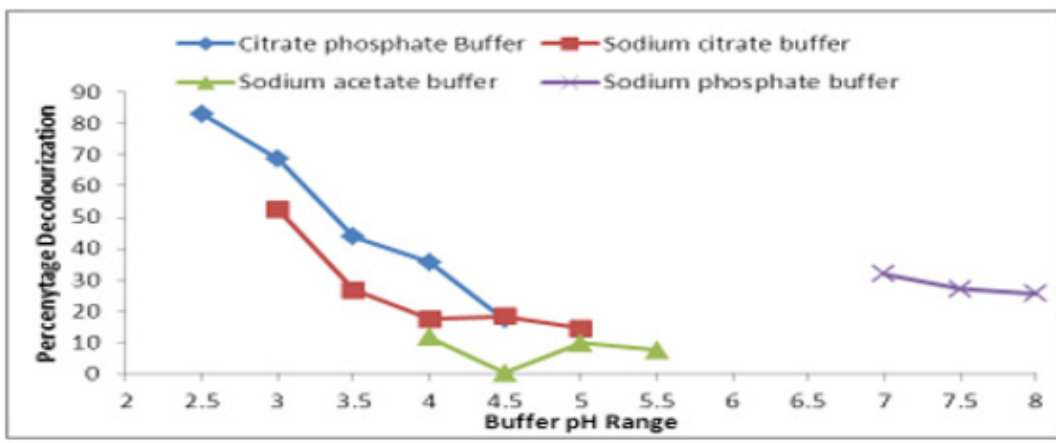

Figure 1: Selection of buffer and pH for maximum decolorization of dye by (a) free and (b) immobilized enzyme.

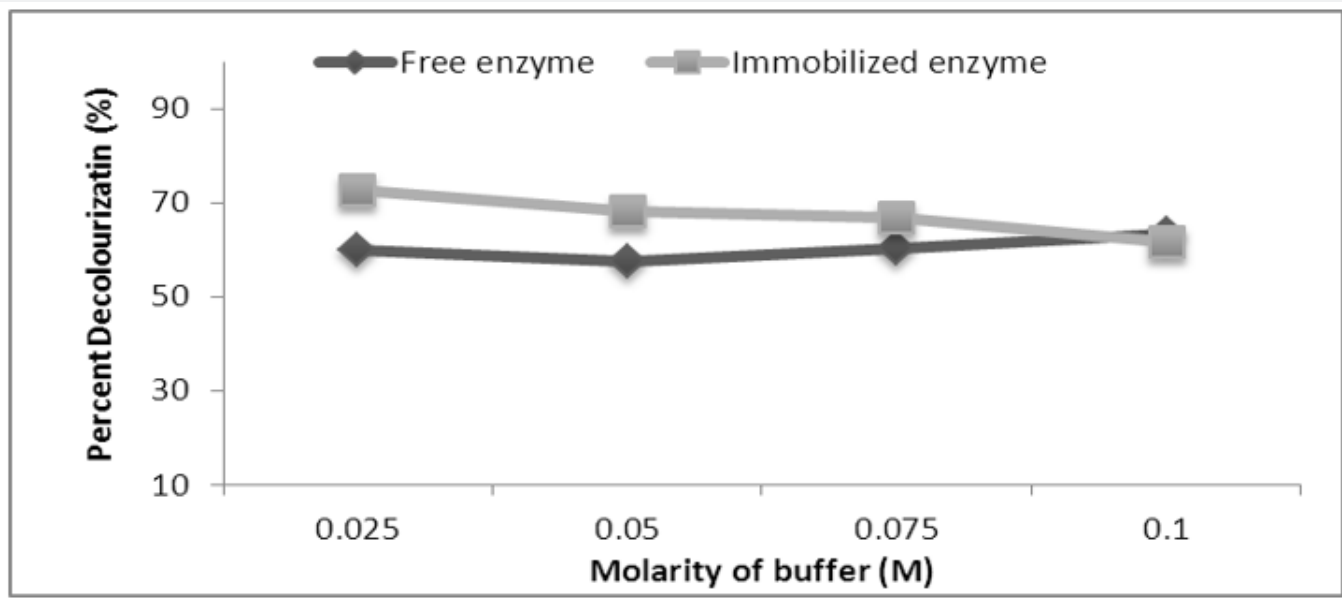

Figure 2: Effect of buffer molarity on dye decolorization with free and immobilized laccase.

Optimization of reaction temperature and incubation time for dye decolorization by free and immobilized enzyme

With increase in temperature $\left(25{ }^{\circ} \mathrm{C}-45{ }^{\circ} \mathrm{C}\right)$, a gradual increment in the percent decolorization of dye by free laccase was observed with maximum decolorization (90\%) at $45{ }^{\circ} \mathrm{C}$ (Figure 4). Increase of temperature to $45{ }^{\circ} \mathrm{C}$ showed constant percent decolorization and further increase resulted in a marked decrease in the dye decolorization. The free enzyme showed maximum percent decolorization of dye after $90 \mathrm{~min}$ (Figure $3)$. These results were similar to the experiment performed by
Khlifi et al. [15] showing mediator based decolorization of azo dyes by laccase from Streptomyces psammoticus. Immobilized laccase showed maximum decolorization $(80 \%)$ at $25{ }^{\circ} \mathrm{C}$ and then a constant percentage of dye decolorization (70\%) with an increase in temperature from $30{ }^{\circ} \mathrm{C}$ to $50{ }^{\circ} \mathrm{C}$. Maximum decolorization (72.14\%) with immobilized laccase was observed after $30 \mathrm{~min}$ of incubation (Figure 3). Further increase in incubation led to no change in the percent dye decolorization due to product inhibition or due to denaturation of the enzyme when incubated for a longer period of time. Similarly, Araujo et al. [16] performed laccase assay of Botryosphaeria sp., Pleurotus ostreatus and Aspergillus sp. with ABTS at $55^{\circ} \mathrm{C}$. 


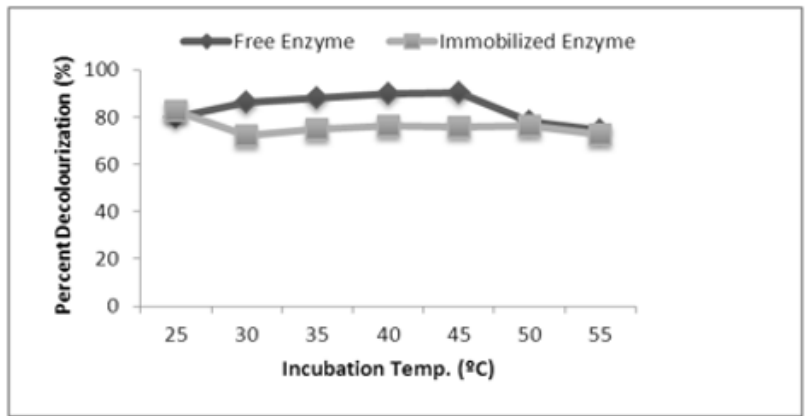

(a)

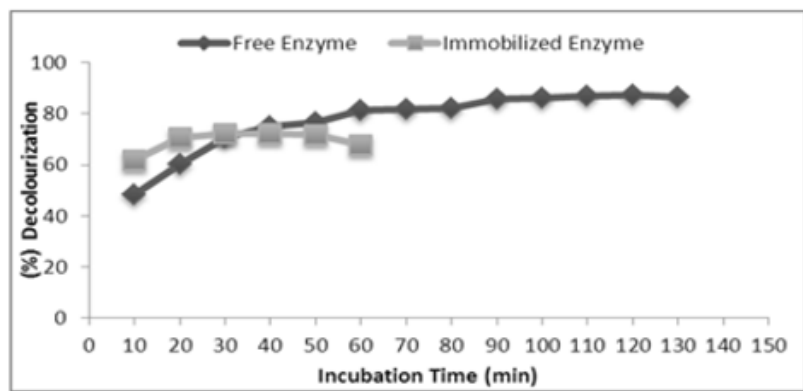

(b)

Figure 3: Optimization of reaction temperature (a) and incubation time(b) for dye decolorization by free and immobilized enzyme.

Optimization of enzyme dose and dye concentration for decolorization of dye using free and immobilized laccase

Dye concentration influence its decolourization rate, therefore free and immobilized enzyme, showed maximum dye decolorization $60 \%$ and $65 \%$ respectively at $100 \mathrm{mM}$ per $1.1 \mathrm{ml}$ reaction mixture (Figure 4). The result revealed that the decolorization remain constant with increasing dye concentration may be due to the substrate inhibition or nonavailability of free enzyme site. Asgher et al. [17] immobilized Pleurotus ostreatus laccase by entrapping in sol-gel matrix which had anoptimum substrate concentration $0.5 \mathrm{mM}$ for immobilized laccase.

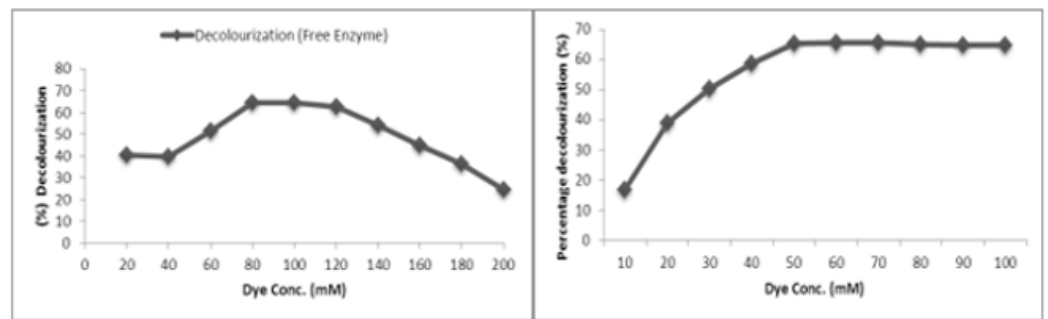

(a)
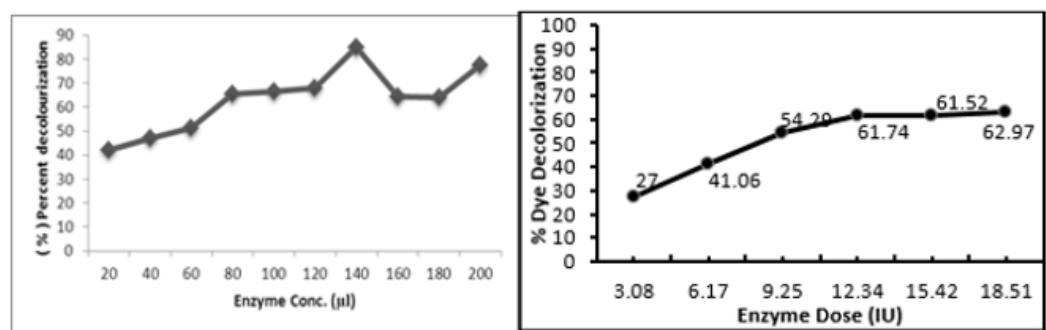

(b)

Figure 4: Optimization of (a)dye concentration and (b)enzyme dose for decolorization of dye using free and immobilized laccase.

For the maximum decolorization of methyl orange dye, enzyme dose (IU)of immobilized enzyme and free enzyme were optimized. Decolorization increased as enzyme dose increased from 3.08 IU to 18.51 IU with maximum decolorization (61.7\%) with 12.34 IU ( 20 beads) in case of immobilized enzyme and $140 \mu \mathrm{l}$ of crude fee enzyme (80\%) (Figure 4). The minimum 
enzyme dose for maximum decolorization was found to be 12.36 U. At the zone of equivalence between enzyme and substrate, further increase in enzyme dose showed no enhancement in decolorization level. A similar observation by Soares et al. [18] and Saito et al. [19] were reported in their studies using the crude or purified laccase.

\section{Selection of efficient mediator for the decolorization of methyl orange dye by free and immobilized laccase enzyme}

Mediators generally enhance the activity of enzyme, therefore effect of various mediators like PABA, HOBT, PHBA, Pyrogallol, ABTS etc were checked with free and immobilized laccase for maximum dye decolorization. In the presence of HOBt mediator, free enzyme showed maximum (97.03\%) dye decolorization. Khalifi et al. [15] also used Laccase-HBT system for removal and elimination of synthetic dyes and characterized thisas one of the most successful laccase mediated system. Immobilized enzyme was showing (77.98\%) maximum dye decolorization in the presence of Pyrogallol (Figure 5). Similar results were shown by Zamora et al. [20], where maximum decolorization of reactive dyes was obtained by immobilized laccase (Trametes versicolor) in the presence of the mediator. Papinutti et al. [21] showed the proportional relationship between the concentrations of HBT and destructive effect of the $\mathrm{N}-\mathrm{O}$ group on laccase mediating the decolourization effect.

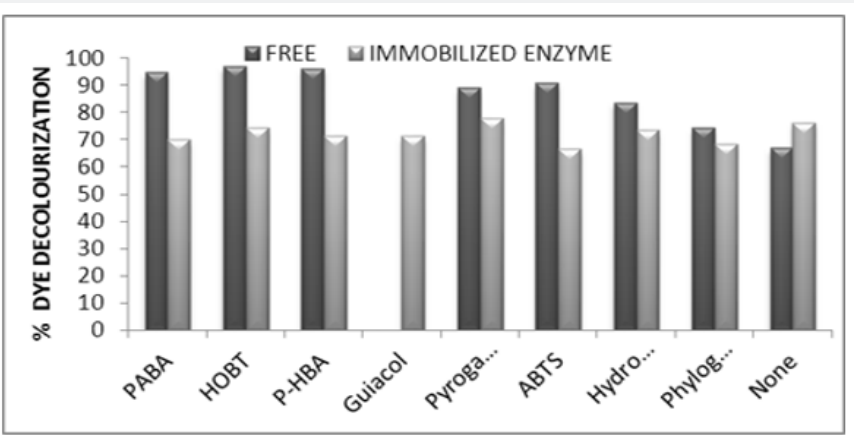

Figure 5: Effect of different mediators on dye decolorization using free \& immobilized enzyme

\section{Reusability of immobilized laccase enzyme}

Immobilization of laccase enzyme on alginate, reduces the production cost and facilitate its industrial application of dye decolourization due to the property of reusability of entrapped laccase enzyme. Reusability of the immobilized enzyme for dye decolorization was assayed at $25 \stackrel{\circ}{\circ} \mathrm{C}$ for 30 min repeatedly till the activity decreased to about $50 \%$ or less. We investigated the reusability of the immobilized enzyme for up-to eight cycles and showed, that till 7th reaction cycles the activity of immobilized was reduced to only $50 \%$ showing the advantage of immobilized laccase for the dye decolorization (Figure 6). The probable explanation may be decrease in pore size of alginate beads causing difficulties in the dye diffusion during enzymatic reaction leading to decreased efficiency of laccase entrapped in alginate bead. Successful reuse of activated polyvinyl alcohol with $60 \%$ activity after ten cycles and amine-terminated magnetic nano-composites with $80 \%$ activity after 5 cycles were already documented in the literature [22-24].

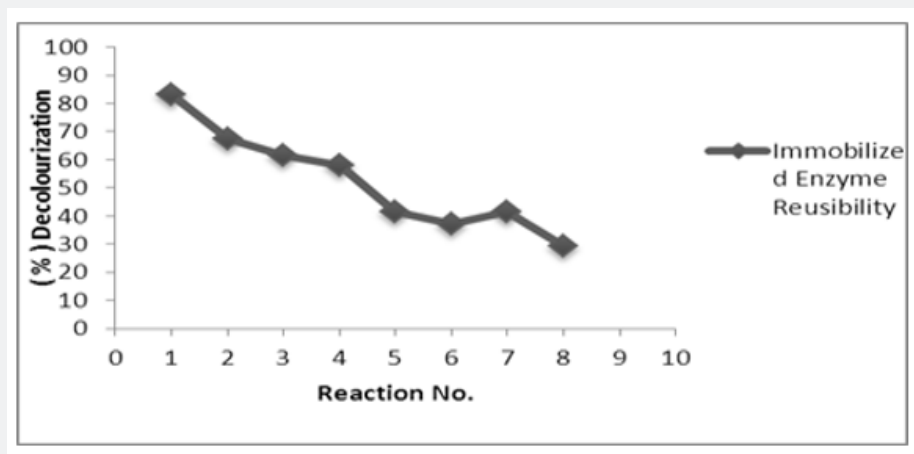

Figure 6: Reusability of immobilized laccase enzyme

\section{Batch and fed batch decolorization of methyl orange dye $(500 \mathrm{ml})$ using Bio Flo Neo fermenter}

All the optimum conditions were applied for the decolorization of methyl orange dye using fermenter $(500 \mathrm{ml})$ in batch and fed-batch with both free and immobilized laccase enzyme. In both batch and fed-batch level with free enzyme, the total reaction volume was $500 \mathrm{ml}$ comprising buffer $(327 \mathrm{ml})$, laccase enzyme $(64 \mathrm{ml})$, methyl orange dye $(45 \mathrm{ml})$ and HOBT mediator $(64 \mathrm{ml})$. In Batch, all the reaction components are added once in the fermenter and then 6 aliquots of $1100 \mu$ l were 
drawn at a regular interval of 10 minutes. In case of in fed batch, dye was added in the fermenter in 6 feedings of $7.5 \mathrm{ml}$ each and O.D. was observed at $508 \mathrm{~nm}$.

With immobilized laccase on calcium alginate beads, the batch fermenter level was operated for 30 minutes at $25{ }^{\circ} \mathrm{C}$. In a batch process of $500 \mathrm{ml}$ total reaction volume consisting of $455 \mathrm{ml}$ buffer, $25 \mathrm{ml}$ dye, $20 \mathrm{ml}$ mediator, 6000 no's Beads, all the components was added once and after every 10 minutes, $1000 \mu \mathrm{l}$ volume aliquots was withdrawn, to find the percentage decolorization of methyl orange dye . In fed batch, 3 feedings ( $8.33 \mathrm{ml}$ each)of methyl orange dye were added to the fermenter reaction volume and O.D. was observed to find out the percentage decolorization of methyl orange dye. At the $500 \mathrm{ml}$ fermenter level, our experiment showed less dye decolorization. With free enzyme, batch and fed batch showed inverse relationship and fed batch failed in dye decolourization. In case of immobilized enzyme, we achieved positive results with both batch and fed batch (Figure 7).

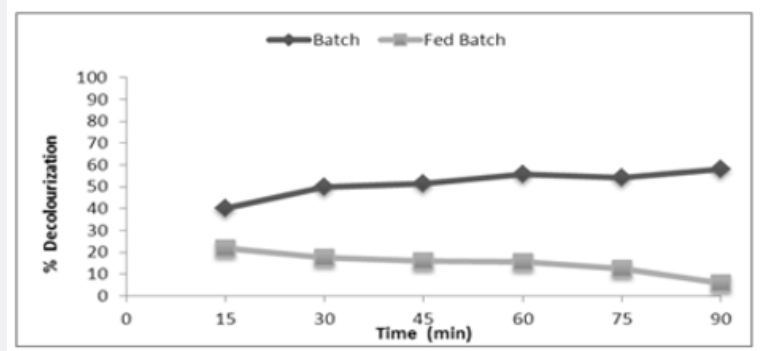

(a)

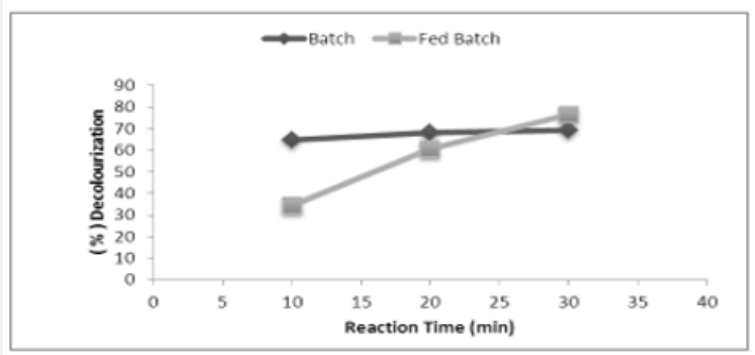

(b)

Figure 7: Decolorization of dye with optimized conditions in batch and fed-batch using(a) free and (b) Immobilized laccase enzyme.

\section{Conclusion}

Cercospora $s p$. is an interesting microorganism and so far no one reported laccase production from this class of fungus. Being versatile oxidases and owing high reduction potential, makes laccase enzyme a potential candidate for biotechnological application especially in bioremediation [25]. These enzymes inherit the property for degrading phenolic, non-phenolic ligninrelated compounds, recalcitrant environmental pollutants, xenobiotic compounds and therefore can be effectively used in bioremediation [26]. Laccase from Cercospora sp. SPF-6 permits several possible interactions with different matrices. Laccase was immobilized on calcium alginate beads by entrapment method and used as stable matrix system compared to free enzymes considered an advantage in wastewater treatment. Additional reusability of laccase entrapped beads provides economic benefits when used in large scale application such as in fermenter or bioreactors. Many researchers have showed potentiality of both microorganism and laccase enzyme for the treatment of dye and textile effluents [27].

On the basis of the present study, it would be concluded that immobilized laccase has better potential in the decolorization of methyl orange dye present in various industrial effluents and waste water. The improved stability and reusability could be a potential advantage in wastewater treatment. Because of the potential use in the bioremediation and detoxification of pollutants, interest in laccases has increased [28]. Stable and reliable source of enzyme with ease of extraction was produced from microbial world [29]. Media optimization and use of appropriate inducers could bring additional benefits of higher production with expenditure of minimum resources. Understanding a better mode of cultivation using mediators, possibly extend the role of laccase to non-phenolic substrates [30]. So far, this is the first report demonstrating the decolorizing activity in the Cercospora genre. To illuminate its full potential, further studies should be carried for more efficient laccase production system.

\section{Acknowledgment}

The authors acknowledge the Department of Biotechnology, Himachal Pradesh University for arranging the excellent working conditions for us. The authors acknowledge the financial support from University Grant Commission (UGC), New Delhi. Special thanks to Dr. Anita Verma for assistance and guidance in research work. 


\section{Conflict of Interest statement}

The authors have no conflicts of interest with the contents of this article

\section{References}

1. Kunamneni A, Ghazi I, Camarero S, Ballesteros A, Plou FJ, et al. (2008) Decolorization of synthetic dyes by laccase immobilized on epoxyactivated carrier. Process Biochem 43(2): 169-78.

2. Srinivasan A, Viraraghavan T (2010) Decolorization of dye wastewater by bio-sorbents. J Environ Manage 91(10): 1915-1929.

3. Parshetti GK, Telka AA, Kalyani DC, Govindwar SP (2010) Decolorization and detoxification of sulphonated azo dyes methyl orange by Kocuria rosea MTCC 1532. J Hazard Mater 176(1-3): 503-509.

4. Cañas AI, Camarero S (2010) Laccases and their natural mediators: Biotechnological tools for sustainable eco-friendly processes. Biotech Adv 28(6): 694-705.

5. Riva S (2006) Laccases: blue enzymes for green chemistry 2006. Trends Biotechnol 24(5): 219-226.

6. Munusi RC, Rossi M, Bologna L, Rotilio D, pastore GM, et al. (2007) Phenols removal in musts: Strategy for wine stabilization of laccase. Mol Catal B: Enzymatic. 45(3-4): 102-107.

7. Nagai M, Kawata M, Watanabe H, Ogawa M, Saito K, Takesawa T, et al. (2003) Important role of fungal intracellular laccase for melanin synthesis: purification and characterization of an intracellular laccase from Lentinula edodes fruit bodies. Microbiology 149(9): 2455-2462.

8. Bradford MM (1979) A rapid and sensitive for the quantitation of microgram quantities of protein utilizing the principle of protein-dye binding. Anal Biochem 72: 248-254.

9. Noeru M, Sawhney SK (2002) Stability and properties of Mushroom tyrosinase entrapped in alginate polyacrylamide and gelatin gels. Enzyme Microbial Technol 30(5): 613-619.

10. Palmieri G, Giardina P, Bianco C, Scaloni A, Capasso A, et al. (1997) A novel white laccase from Pleurotus ostreatus. J Biol Chem 272(50): 31301-31307.

11. Kandelbauer A, Erlacher A, Cavaco A, Guebitz GM (2004) Laccasecatalyzed decolorization of the synthetic azo-dye diamond black PV 200 and of some structurally related derivatives. Biocatal Biotransfor 22: 331-39.

12. Nyanhongo GS, Gomes J, Gubitz G, Zvauya R, Read JS, et al. (2002) Production of laccase by a newly isolated strains of Trametes modesta. Bioresource Technol 84(3): 259-263.

13. Palmieri G, Cennamo G, Faraco V, Amoresano (2004) A typical laccase isoenzymes from copper supplemented Pleurotusostreatus cultures. Enzyme Microb Tech 33: 220-230.

14. Lu L, Zhao M, Wang Y (2007) Immobilization of laccase by alginatechitosan microcapsules and its use in dye decolorization. World Microb Biot 23(2): 159-166.

15. Khalifi R, Belbahri L, Woodward S, Ellouz M, Dhouib A, et al. (2010) Decolorization and detoxification of textile industry wastewater by the laccase-mediator system. J Hazard Mater 175(1-3): 802-808.
16. Araújo JHB, Uemural VO, Moraes FF, Barbosa AM, Zanin GM (2005) Comparative study on fungal laccases immobilized on chitosan. Braz Arch Biol Techn 48: 1-6.

17. Asgher M, Fafiz NIM, Javed A (2012) Kinetic characterization of purified laccase produced from Trametes versicolor IBL-04 in solid state bioprocessing of corncobs. Bioresources 7: 1171-1188.

18. Soares GMB, Costa-Ferreira M, Amorim MTP (2001) Use of laccase together with redox mediators to decolorize Remazol Brilliant Blue R. J Biotechnol 89(2-3): 123-129.

19. Saito T, Hong P, Kato K, Okazaki M, Inagaki H, et al. (2003) Purification and characterization of an extracellular laccase of a fungus (family Chaetomiaceae) isolated from soil. Enzyme Microb Tech 33(4): 520526 .

20. Zamora PP, Pereira CM, Tiburtius ERL, Moraes SG, Rosa MA, et al. (2003) Decolorization of reactive dyes by immobilized laccase. Appl Catal B-Environ 42(2): 131-144.

21. Papinutti L, Dimitriu P, Forchiassin F (2008) Stabilization studies of Fomes schlowdermus laccases. Bioresource Technol 99(2): 419-424.

22. Vishal Gupta N, Gowda D, Balamuralidhara V, Mohammed Khan S (2011) Formulation and evaluation of olanzapine matrix pellets for controlled release. J Pharm Sci 19(4): 249-256.

23. Mutti FG, Pievo R, Sgobba M, Gullotti M, Santagostini L (2008) Biomimetic modelling of copper complexes: a study of enantio selective catalytic oxidation on D-(+)-catechin and L-(-)-epicatechin with copper complexes. Bioinorg Chem Appl doi: 10.1155/2008/762029.

24. Xiao HY, Huang J, Liu C, Jiang DS, De-sheng, et al. (2006) Immobilization of laccase on amine-terminated magnetic nanocomposite by glutaraldehyde crosslinking method. T Nonferr Metal Soc 16(supplement 1): 414-418.

25. Chandra R, Chowdhary P (2015) Properties of bacterial laccase and their application in bioremediation of industrial wastes. Environ Sci Process Impacts 17(2): 326-342.

26. Viswanath B, Rajesh B, Janardhan A, Kumar AP, Narasimha G (2014) Fungal laccases and their applications in bioremediation. Enzyme Res doi: $10.1155 / 2014 / 163242$.

27. Fazli MM, Mesdaghinia AR, Naddafi K, Nasseri S, Yunesian M, et al. (2010) Optimization of reactive blue $19 \mathrm{G}$ colorization by Ganoderma sp. using response surface methodology 2010. Iran J Environ Health Sci Eng 7: 35-42.

28. Singh G, Bhalla A, Kaur P, Capalash N, Sharma P (2011) Laccase from prokaryotes: a new source for an old enzyme. Environ Sci Biotechnol 10(4): 309-326.

29. Desai SS, Nityanand C (2011) Microbial laccase and their applications: A Review. Asian J Biotechnol 3(2): 98-124.

30. Khambhaty Y, Ananth S, Sreeram KJ, Rao JR, Nair BU (2015) Dual utility of a novel, copper enhanced laccase from Trichoderma aureoviridae. Int J Biol Macromol 81: 69-75. 
(C) This work is licensed under Creative (1) Commons Attribution 4.0 Licens BY DOI:10.19080/AIBM.2018.11.555813
Your next submission with Juniper Publishers will reach you the below assets

- Quality Editorial service

- Swift Peer Review

- Reprints availability

- E-prints Service

- Manuscript Podcast for convenient understanding

- Global attainment for your research

- Manuscript accessibility in different formats

( Pdf, E-pub, Full Text, Audio)

- Unceasing customer service

Track the below URL for one-step submission https://juniperpublishers.com/online-submission.php 